PUBS.

Guy R. Martin-Commissioner

Information Circular 22
State of Alaska

Department of Natural Resources

\title{
PROGRESS AND PROSPECTS IN MARINE MINING IN ALASKA
}

\author{
By Cleland N. Conwell ${ }^{1}$
}

\begin{abstract}
Overview of Marine Mining
Marine mining is defined "a commercial recovery of minerals other than oil and gas from the surface of or below the seabed by operations connected only indirectly with land (i.e., by ships or pipelines)."

A great deal has been said and written-particularly in the last decade-about the mineral potential of the seabed. The demand for most minerals and mineral base commodities has increased at almost an exponential rate. Accompanied by the demand has been a considerable and steady increasing effort devoted to research and development of new technologies needed for marine mining. However, the number of operations falling within the definition of marine mining and the number of countries involved are remarkably limited. Indeed, as if to mirror the increasing demand for minerals concerned, the volume of literature on marine mining also seems to be increasing exponentially-it is almost to the point where it is tempting to suggest that publishing is the largest sector of the marine mining industry.
\end{abstract}

The current status of mining, research, and commodities may be classified in six categories:

1) The production of sulfur from offshore wells.

2) Marine manganese nodules.

3) Phosphorites.

4) Sand, shells, and gravels from the marine bed.

5) Marine placer mining.

6) Hard-rock mining under the ocean.

In the last category, a distinction is made between marine mining, such as the barite mine near Petersburg, Alaska and mining under the sea, such as at Breton Island, Nova Scotia. Near Petersburg, the definition of marine mining strictly applies. At Breton Island, coal is mined from slopes on shore extending out and under the ocean. Another possibility is using an artificial island to mine under the ocean, as has been considered off the coast of Japan.

Of the types of mining under the sea, undoubtedly the greatest effort, expenditure, and literature has involved the recovery of manganese nodules from the sea floor. The nodules are found in deep water, beyond the continental shelves, and offer unique problems in international law concerning ownership.

\footnotetext{
${ }^{1}$ DGGS mining engineer.
}

The smallest amount of research but greatest monetary value has been and will continue to be the recovery of sands, gravels, shells, and silts from the ocean floor. This particular type of mining, accomplished by the suction dredge, has diverse objectives, ranging from reclaiming land from the sea, supplying aggregates for the construction industry, and supplying shells as a substitute for limestone to improving harbors.

Only five minerals have been recovered commercially by marine mining: gold, diamonds, sulfur, barite, and cassiterite (tin). These minerals come from but four areas in the world: gold and barite from Alaska, diamonds from South Africa, sulfur from the Gulf of Mexico, and tin from Thailand. The offshore potential for recovery of tin appears excellent and Malaysia, Indonesia, and Thailand signed an agreement to draw up continental shelf boundaries in the northern parts of the Straits of Malacca. The Sunda Shelf of Indonesia appears particularly attractive for new tin placers.

\section{Offshore Mining in Alaska}

Offshore placer mining operated prior to 1940 near Golovnin Bay. When the ice was thick enough to support a "clam shell" scoop and truck, holes were cut through the ice. Sand and gravels were brought from the ocean floor with the clam shell, loaded into trucks, and transported to the shore for sluicing during the summer months. In Sloanes' History of American Mining, reference is made to hard-suited divers going under the ice at Nome to both explore and placer mine at the turn of the century.

The only Alaskan operating offshore mine today is the mine on Castle Island, near Petersburg (fig. 1); it is owned by the Chromalloy Company. Mining in earnest started on this small outcrop about 1963 on the barite above the high tide mark. As time went on, mining had to be conducted at low tide.

Since about 1967, the mining has been offshore. The system is unique. The ore is drilled and blasted under water. The broken material is then recovered by a clam shell and loaded onto a bottom-dump barge, which is towed close to shore and opened. This rock is then pulled ashore with a drag line, crushed, and stock piled. The barite was then loaded directly onto an ocean vessel in lots of 20,000 tons or more. About 100,000 tons of barite were mined each year.

In 1974 , a heavy-media vessel was added to permit 


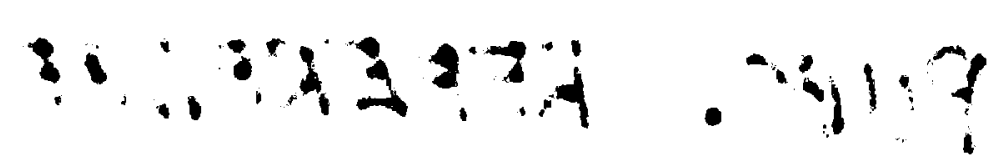

processing of impure barite, thereby extending the life of the mine. A grinding mill and bagging plant were also added; they were mounted on a converted World War II LST that had been beached near Kenai, Alaska. The LST was then floated, towed to Castle Island, and rebeached. About 15,000 tons of finished product are now produced annually.

\section{Current Status of Leases}

Figure 1 shows the beached LST containing the barite grinding mill and bagging plant in the background; prepared and pelletized bags of barite are in the foreground.

The current (as of May 1, 1976) offshore mining leases are listed in the table below. The current status of these leases is: American Smelting and Refining Company has a continuing active exploration, bulk testing, metallurgical, and environmental impact program. The lease has been evaluated by drilling (in the winter through the ice) and the gold resource measured. The Asarco lease contains the largest known offshore gold resource. The drill sampling has been checked for accuracy by bulk sampling with a barge-mounted drag line. The bulk sample, which has proven the reliability of the drilling, has to be subjected to pilot-scale metallurgical testing for recovery and separation techniques. Several marine-bottom studies have been made relating to environmental impact, including a contract with the UA Institute of Marine Science. No date has been set to start active mining.

The offshore mining leases by the U.S. \& R. Co. are inactive.

The offshore mining lease of the Auric Mining Co. and adjoining prospecting permits have a gold resource. Dr. Robert Moore, Professor of Geology and Director of the Marine. Research Laboratory of the University of Wisconsin, has been investigating the marine placers near Golovnin Bay. His work has included marine studies of environmental quality as well as sampling techniques.

At Goodnews Bay the leases are held by Inlet Oil. Here again, Dr. Moore has been the principal investigator, and he and his students have been active in the area for several years. Both Goodnews and Chagvan Bays have a platinum resource, particularly in Goodnews Bay (where the leases have been granted) the platinum is in a very small size (less than 200 mesh) and recovery by conventional gravity methods is not adequate. Additional sampling, metallurgical research and testing will be required to change the resource to a reserve.

The U.S. Steel lease in the Haines area is inactive. The iron mineral is magnetite, and the magnetite is allegedly titaniferous. There seems to be periodic interest in both the offshore and onshore residual iron deposits. The resource is large, possibly $1 / 2$ billion tons of iron, but economics and mineral preparation are primary deterrents to development.

The Prince of Wales Mining Company, located in the Ketchikan district, is inactive. Robert Tomson of Ketchikan has applied for a lease offshore of Revillagigeo Island. In the Behm Canal, in one area at low tide, the writer sampled sands that contained 0.016 ounces of gold per ton, and identified the heavy minerals as garnet, zircon, and ilmenite.

In addition to the areas under active lease, the following areas have a high potential for placers:

a) Kotzebue Sound-Candle to Deering: Gold placer.

b) Tip of Seward Peninsula - Shismaref to Wales to Lost River: Tin.

c) Kuskokwim Delta - Goodnews Bay: Gold and platinum.

d) Togiak Bay - Togiak: Gold.

e) Shelikof Strait - Ugak Bay: Gold.

g) Tuxedni Bay - Tuxedni Bay: Iron (magnetite).

h) Gulf of Alaska - Yukutat-Yakataga to Lituya Bay: Gold and heavy minerals, possibly fissonable minerals resource.

j) South-central Alaska - Bradfield Canal: Gold, garnet, magnetite, ilmenite.

In addition to the offshore mining, there is a possibility of mining coal under the ocean in the Chignik area. Present geologic knowledge indicates conditions more favorable to coal mining may exist under the ocean than on land (i.e., gentler dips and fewer faults). Another form of mining would be in-situ gasification or solution mining of coals under the Cook Inlet. DGGS petroleum geologist Don McGee has examined oil-well logs, and says there is a potential energy resource-coalthere.

\section{Environmental Problems}

Inasmuch as Alaska has a great potential for (and an excellent probability of) further offshore mining, the

Current owners of offshore leases

$\frac{\text { Lessee }}{\text { UV Industries }}$
American Smelting and Refining
Auric Offshore Mining
Prince of Wales Mining
Inlet Oil
Chromalloy
U.S. Steel

\begin{aligned} \multicolumn{1}{c}{ Acres } & Commodity \\ 5,786 & Gold \\ 15,365 & Gold \\ 1,287 & Gold \\ 10 & Gold \\ 2,875 & Platinum \\ 200 & Barite \\ 153 & Iron \end{aligned}

\section{Location}

Seward Peninsula, near Nome Seward Peninsula, near Nome Seward Peninsula, Golovnin Bay Near Ketchikan, southeastern Alaska Goodnews Bay, southwestern Alaska Castle Island, southeastern Alaska Near Haines, southeastern Alaska 
environmental impact should be determined. The present offshore mining (barite) is being conducted with very little effect on the environment. The sea remains blue, and the actual location of mining can only be determined by the location of the barge. Likewise, offshore placer mining should have no permanent environmental damage. The temporary effect would be the release of particulate matter from bottom muds and an increase in turbidity in the small area affected by the dredging. Despite this and the inevitable discharge of human waste and other refuse in the area of mining, the healing effect should be rapid and there would be no lasting ill effects on marine life. Members of marine science groups have stated that a mud bottom is more productive to marine life than is a gravel bottom. With the proper technology, the mined area could be restored to a more productive environment after mining than it had before.

The major hazard of marine mining could be interference with transportation corridors. Marine navigation aids would have to be established to clearly mark stationary marine hazards. Another marine hazard is the millions of tons of explosives that were dumped into the sea 30-odd years ago. In western Alaska, unknown quantities of unexploded ordnance from the World War 'I Aleutian theater may pose a safety hazard. More recently, the dumping of ordnance off the coast of southern California led to the cancelation of a phosphate lease.) There is still another safety hazard in marine exploration and mining-storms. However, little can be done to alleviate Nature's furies.

The recreational resources near the beaches and shore communities would be affected somewhat by offshore mining. However, the impact would be limited and would most likely create no serious interference. On the other hand, communities would financially benefit from the broader economic base.

The state of Alaska has approximately 20,000 acres under lease. These leases were awarded because of proven resources. In addition, there were $1,158,250$ acres held on offshore prospecting permits as of March 31,1976 . Offshore mining may have a significant impact on Alaska-after all, Alaska has more coastline than all of the contiguous states combined.

\section{REFERENCES}

Bates, R.G., and Wedow, H., 1953, Preliminary summary review of thorium-bearing mineral occurrences in Alaska: U.S. Geol. Survey Cir. 202, 13 p.

Beatty, W.B., 1972, ABC's of industrial minerals - barite: Mining Congress Journal, $58(2): 81-82$.

Berryhill, R.V., 1963, Reconnaissance of beach sands, Bristol Bay, Alaska: U.S. Bur. Mines Rept. Inv. 6214,48 p.

_—, 1962, Reconnaissance sampling of beach and rivermouth deposits, Norton Bay and Kotzebue Sound, Seward Peninsula, Alaska: U.S. Bur. Mines open-file report, $13 \mathrm{p}$.

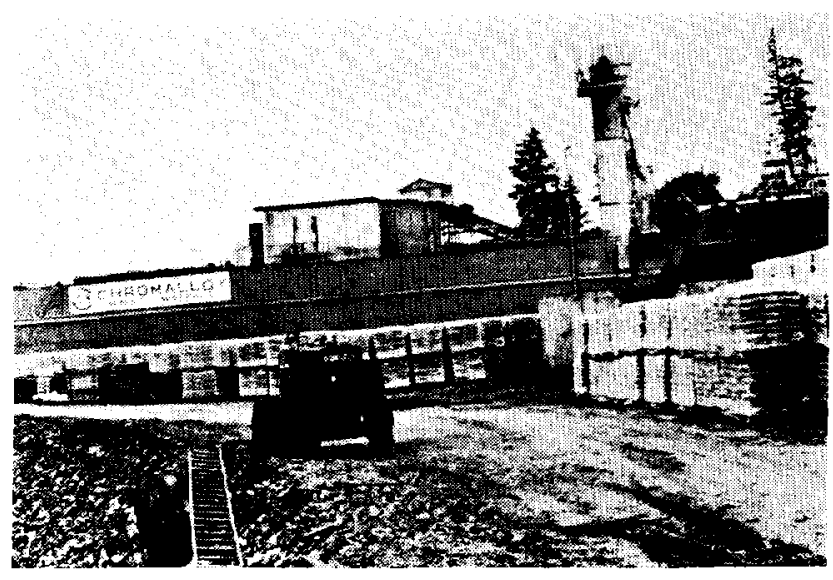

Figure 1. Chromalloy barite mine in southeastern Alaska. Note beached WW II LST in background.

Cobb, E.H., and others, 1968, Summary report on the geology and mineral resources of the Bering Sea, Bogoslof, Simeonof, Semidi, Tuxedni, St. Lazaria, Hazy Islands, and Forrester Island National Wildlife Refuges, Alaska: U.S. Geol. Survey Bull. 1260-K, $28 \mathrm{p}$.

Conwell, C.N., 1976, Industrial barite: Alaska Div. of Geol. and Geophys. Surveys 1974-75 annual report, p. 32 and 34 .

Cook, D.J., 1969, Heavy minerals in Alaskan beach sand deposits: Mineral Industry Research Lab., University of Alaska, College, Rept. 20, $114 \mathrm{p}$.

Cook, D.J., and Roa. P.D., 1970, Distribution, analysis and recovery of fine gold and alluvial deposits: Mineral Industry Research Lab., University of Alaska, 165 p. (unpub.).

Eakins, G.R., 1970, Mineralization near Stepovak Bay, Alaska Peninsula, Alaska: Alaska Div. of Mines and Geology, Special Rept. 4, 12 p.

_, 1969, Uranium in Alaska: Alaska Div. of Mines and Geology, Geol. Rept. 38, 50 p.

Grant, M.J., 1973, Rhode Island's ocean sands-management guidelines for sand and gravel extraction in State waters: Kingston, University of Rhode Island, The Coastal Resources Center, Marine Technology Rept. 10, 51 p.

Grantz, A., 1956, Magnetite deposits at Tuxedni Bay, Alaska: U.S. Geol. Survey Bull. 1024-D, p. 95-106.

Harris, K.L., 1974, Tin: Minerals yearbook, v. 1, 1972, Metals, minerals and fuels, U.S. Bur. Mines, U.S. Gov. Printing Office, 1974, p. 1223.

Hopkins, D.M., 1968, Placer deposits in north Bering sea in report for the year 1967: Alaska Div. of Mines and Minerals, p. 56-57.

Hopkins, D.M., MacNeil, F.S., and Leopold, E.B., 1969, The coastal plain at Nome, Alaska: A late Cenozoic type section for the Bering Strait region, in Report of the 21st International Geological Congress, Copenhagen, 1969; p. 46-57.

Howard, T.E., and Padan, J.W., 1966, Problems in evaluating marine mineral resources: Mining Engineering, $18(6): 57-61$.

_ 1966 , Problems in evaluating marine mineral resources: Paper for presentation at the 1966 Pacific 
Northwest Minerals and Metals Regional Conference, American Institute of Mining, Metallurgical and Petroleum Engineers, April 21-22, Seattle, Wash.

Hutchins, J.P., 1907, Dredging beach gravel deposits near Nome (Alaska): Engineering and Mining Journal, 84: 955-961.

Hwang, Cheng-Liang, 1974, Design of a system for evaluation and recovery of minerals from beach sand deposits: University of Alaska, College, M.S. thesis, p. 22-28.

Jenkins, R.L. and Lense, A.H., 1967, Marine heavy metals project, offshore Nome, Alaska, July-August 1967: U.S. Bur. Mines Tech. Prog. Rept. (HeavyMetals Program), 11 p.

Johnson, G.R., and Plafker, G., 1969, Preliminary geologic interpretation of aeromagnetic data in the Yakutat district, Alaska: U.S. Geol. Survey open-file report, 13 p. (scale $1: 63,360$ ).

Kimball, A.L., 1972, Reconnaissance of Ugashik beach sands, Bristol Bay, Alaska: U.S. Bur. Mines open-file rept. 21-72, $28 \mathrm{p}$.

Knebel, H.J., and Creager, J.S., 1974, Heavy minerals of the east-central Bering Sea continental shelf: Journal of Sed. Petrology, 44(2):553-561.

Lewis, J.R., 1972, Tin: Minerals yearbook, v. 1, 1970, Metals, minerals, and fuels, U.S. Bur. Mines, U.S. Gov. Printing Office, 1972 , p. 1104.

Luepke, G., 1975, Heavy-mineral trends in the Beaufort Sea: U.S. Geol. Survey open-file rept. 75-667, 26 p.

McGee, D.L., and O'Connor, K.M., 1975, Mineral resources of Alaska and the impact of Federal land policies on their availability: Alaska Div. of Geol. and Geophys. Surveys open-file rept. 51, 29 p., 7 fig.

McKelvey, V.E., and Wang, F.F.H., 1970, World subsea mineral resources; preliminary maps: U.S. Geol. Survey Misc. Geol. Inv. Map I-632, 17 p., 4 maps.

McKelvey, V.E., Tracey, J.I., Stoertz, G.E., and Vedder, H.G., 1969, Subsea mineral resources and problems related to this development: U.S. Geol. Survey Circ. 619,26 p.

MacKevett, E.M., and others, 1971, Mineral resources of Glacier Bay National Monument, Alaska: U.S. Geol. Survey Prof. Paper 632, 90 p.

Maddren, A.G., 1918, The beach placers on the west coast of Kodiak Island, Alaska, in Mineral resources of Alaska: U.S. Geol. Survey Bull. 692, p. 299-319.

Martin, G.C., 1913, Mineral deposits of Kodiak and the neighboring Islands: U.S. Geol. Survey Bull. 542, p. 134-136.

Moore, J.R. and Welkie, C.J., 1976, Metal-bearing sediments economic interest, coastal Bering Sea, Marine Research Lab., University of Wisconsin, Madison, $25 \mathrm{p}$

Moxham, R.M., 1952, Radioactive pegmatite minerals in the Yakataga beach placers in reconnaissance for radioactive deposits in south-central Alaska 1947-49: U.S. Geol. Survey Cir. 184, pt. 3, p. 11-14.

_. 1969 , Potential development of heavy metal resources in the northern Bering Sea, in Science in Alaska: Proceedings of the 20th Alaska Science Conference, College, American Assoc. for the Advancement of Science, Alaska div. p. 366-376.

Nelson, C.H., and Hopkins, D.M., 1972, Sedimentary processes and distribution of particulate gold in the northern Bering Sea: U.S. Geol. Survey Prof. Paper $689,27 \mathrm{p}$.

_, 1968, Concentration of particulate gold in sediments of the northern Bering Sea, in Program abstracts of the 81 st Geologic Society of America Annual Meeting, Mexico City, p. 218-219.

Owen, R.M., and Moore, J.R., 1976, Sediment dispersal patterns as clues to placer-like platinum accumulation in and near Chagvan Bay, Alaska: Paper for presentation at 8 th Offshore Tech. Conference, Houston, May 1976, paper 2453.

Pepper, J.F., 1958, Potential mineral resources of the continental shelves of the western hemisphere: U.S. Geol. Survey Bull. 1067, p. 63-64.

Pittman, T.L., 1971, Notes of Duncan Canal barite mining: unpub. report for Frank Fulkerson, 2 p. (photocopy available from U.S. Bureau of Mines Library, Juneau ).

Race, W.R., 1963, Castle Island barite deposits, Duncan Canal, Alaska, Petersburg, quadrangle: Alaska Div. of Mines and Minerals property examination rept., $13 \mathrm{p}$.

Reynolds makes first barite shipment, 1967, Alaska Construction and Oil Report, Jan., p. 27-28.

Rossman, D.L., 1957, Ilmenite-bearing beach sands near Lituya Bay, Alaska: U.S. Geol. Survey open-file report, 11 p., map (scale 1:250,000).

Sheth, M., 1971, A heavy mineral study of Pleistocene and Holocene sediments near Nome, Alaska: U.S. Geol. Survey open-file report, $83 \mathrm{p}$.

Silberman, M.L., 1969, Preliminary report on electron microscopic examination of surface texture of quartz sand grains from the Bering Shelf: U.S. Geol. Survey Prof. Paper 650-C, p. 33-37.

Slatt, R.M., and Hoskin, C.M., 1968, Water and sediment in Norris Glacier outwash area, Upper Taku Inlet, southeastern Alaska: Jour. Sed. Petrology, 38(2): 434-456.

Sloan, H.N., and Sloan, L.L., 1970, A pictorial history of American mining: Crown Publishers Inc., New York, p. 281, 311, 312.

Stevens, J.J., 1970, Mining the Alaskan seas: Ocean Industry 15(11), p. 47-51.

Stewart, B.D., 1932, The occurrence of gypsum at Iyoukeen Cove, Chichagof Island, Alaska, in Mineral resources of Alaska: U.S. Geol. Survey Bull. 824, p. $173-177$.

Tagg, A.R. and Greene, H.G., 1973, High-resolution seismic survey of an offshore area near Nome, Alaska: U.S. Geol. Survey Prof. Paper 759-A, p. A19. A22.

Thomas, B.I., and Berryhill, R.V., 1962, Reconnaissance studies of Alaskan beach sands, eastern Gulf of Alaska: U.S. Bur. of Mines Rept. Inv. 5986, 40 p.

Tinsley, C.R., 1976, A new picture emerges in deepocean mining: Mining Engineering, April, p. 34-36.

Trumball, J., Lyman, J., Pepper, J.F., and Thomasson, E.M., 1958, An introduction to the geology and mineral resources of the continental shelves of the Americas: U.S. Geol. Survey Bull. 1067, 92 p.

VenkataRathnam, K., 1971, Heavy minerals on the continental shelf of the northern Bering Sea: U.S. 
Geol. Survey open-file report, $93 \mathrm{p}$.

Williams, J.A., and Decker, P.A., 1932, Exploring

Castle Island barite deposit by diamond drilling: Alaska Terr. Dept. of Mines Mineral Rept. 117-1, $43 \mathrm{p}$.

Wright, F.F., 1969, Sedimentation and gold distribution Yakutat Bay, Alaska 4/68-4/69: Institute of Marine
Science, University of Alaska, College, report 69-1, $23 \mathrm{p}$.

Wright, F.F., and Hood, D.W., 1969, Sedimentation and heavy mineral distribution, northeastern Gulf of Alaska continental shelf, Institute of Marine Science, University of Alaska, College, report 69-1, 1 v., unpaged. 